\title{
Antioxidant activities and physicochemical properties of chocolate fermented by Lactobacillus plantarum CK10
}

Hye Rim Kang ${ }^{1}$, So Yae Koh ${ }^{1}$, Ji-yeon Ryu ${ }^{2}$, Ahmed Osman ${ }^{1}$, Chang Kyu Lee ${ }^{3}$, Ji Hee Lim ${ }^{3}$, Hyeon $\mathrm{A} \mathrm{Kim}^{3}$, Geun Hyung $\mathrm{Im}^{3}$, Somi Kim Cho ${ }^{1,2,4,5 *}$

${ }^{1}$ Interdisciplinary Graduate Program in Advanced Convergence Technology and Science, Jeju National University, Jeju 63243, Korea

${ }^{2}$ Faculty of Biotechnology, College of Applied Life Sciences, SARI, Jeju National University, Jeju 63243, Korea

${ }^{3}$ Jekiss Co., Ltd., Research Institute, Jeju 63067, Korea

${ }^{4}$ School of Biomaterials Sciences and Technology, College of Applied Life Sciences, SARI, Jeju National University, Jeju 63243, Korea

${ }^{5}$ Subtropical Horticulture Research Institute, Jeju National University, Jeju 63243, Korea

\section{Lactobacillus plantarum CK10을 이용한 초콜릿 발효 산물의 항산화 활성 및 성분 분석}

강혜림 $^{1} \cdot$ 고소예 $^{1} \cdot$ 류지연 $^{2} \cdot$ 오스만 아흐메드 ${ }^{1} \cdot$ 이창규 $^{3} \cdot$ 임지희 $^{3} \cdot$ 김현아 $^{3} \cdot$ 임근형 $^{3} \cdot$ 김소미 $^{1,2,4,5 *}$

${ }^{1}$ 제주대학교 차세대융복합과학기술협동과정, ${ }^{2}$ 제주대학교 생명공학부, ${ }^{3}$ (주)제키스,

${ }^{4}$ 제주대학교 바이오소재공학과, ${ }^{5}$ 제주대학교 원예산업연구소

\begin{abstract}
In this study, antioxidant activities and physicochemical properties of chocolate fermented with Lactobacillus plantarum CK10 were investigated. The $\mathrm{pH}$ level decreased from $5.26 \pm 0.02$ to $3.98 \pm 0.06$ during fermentation while titratable acidity increased from $5.36 \pm 0.19$ to $13.31 \pm 0.34$. The total polyphenol and flavonoid contents slightly increased during fermentation, but it was numerically negligible. Slight increase and decrease in the radical scavenging activities of chocolate, against DPPH-, ABTS-, and alkyl- radical, were observed during $32 \mathrm{hr}$ of fermentation, but the changes were not statistically relevant. Composition ratios (\% area by GC analysis) of lactic acid, xanthosine, and theobromine increased with fermentation time while hydroxymethylfurfural (HMF) and caffeine decreased after 32 hr of fermentation, in the order of xanthine (22.7\%), theobrome (20.0\%), lactic acid (14.9\%), HMF (9.1\%) and caffeine (9.0\%). However, there was no remarkable changes in theobromine and caffeine contents in chocolate during fermentation.
\end{abstract}

Key words : antioxidant, chocolate, compositional analysis, fermentation, Lactobaillus plantarum

\section{서 론}

발효 기법은 인류와 함께해 온 오래된 기술 중 하나로서 식품, 의약품, 화장품 등 다양한 분야에서 활용되어 왔다.

*Corresponding author. E-mail : phd.kim.somi@gmail.com Phone : 82-64-754-3348, Fax : 82-64-756-3351

Received 26 May 2016; Revised 13 June 2016; Accepted 20 June 2016.

Copyright (c) The Korean Society of Food Preservation. All rights reserved.
그 중에서도 식품 발효는 전 세계적으로 가장 널리 이용되 어 왔으며 여러 음식 문화에서 다양하게 활용되었다(1). 현재까지 많은 연구들을 통해 발효 식품의 생리 활성에 관한 기능이 밝혀졌으며(1-4), 이를 바탕으로 여러 발효 식 품들이 건강기능성 식품으로 주목받고 있다. 유산균은 식 품 발효를 일으키며 발효 식품 특유의 풍미와 향, 식품의 우수한 보존성 및 생리적 기능성을 부여할 뿐만 아니라, probiotics로 작용함으로써 유당불내증의 완화작용, 정장작 용, 병원성세균의 생육억제 작용, 콜레스테롤 저하작용, 항 암작용 등 다양한 질병의 예방과 치료에 기여한다고 보고되 
었다(5-10). 참살이 열풍으로 인하여 건강보조식품에 대한 관심이 증가하면서 발효 음식들이 다시금 주목을 받고 있으 며, 특히 발효 식품 및 발효 화장품은 참살이의 상징적인 키워드로서 많은 소비자로부터 긍정적으로 평가되고 있다 (11). 이에 따라 유산균 발효가 식품의 활성 성분이나 생리 적 기능 변화에 미치는 영향에 대한 연구가 활발하게 진행 되어, Lactobacillus plantarum을 이용한 유산균 발효 및 열 처리가 마늘의 향기성분 및 항산화 활성에 미치는 영향(11), 유산균 발효에 의한 버섯 추출물의 항산화 활성에 대한 영향(12), 김치 유래 lactic acid bacteria에 의한 양배추 즙의 발효 특성(13), 유산균 발효에 의한 인삼 열매 추출물의 항산화 및 항노화 효과(5), 유산균 발효에 의한 톳 추출액의 이화학적 및 관능적 특성 변화(3), 김치 유래 유산균을 이용 한 단호박 발효음료 제조 기술 개발(14) 등이 보고되고 있다.

특유의 향기와 풍미로 인해 폭넓은 연령층이 선호하여 오랜 시간동안 많이 소비되고 있는 대표적인 기호 식품인 초콜릿(chocolate)은 테오브로마 카카오나무(Theobroma cacao)의 카카오 종자를 원료로 하여 설탕, 우유, 버터 등 다양한 식품원료를 가하여 가공한 것으로, 코코아 가공품 인 코코아 매스, 코코아 버터, 코코아 분말 등에 당류와 유가공품 및 식품 첨가물 등을 혼합하고 성형함으로써 전체 코코아 고형분 $35 \%$ 이상, 또는 코코아 버터 $18 \%$, 무지 코코 아 분말 $14 \%$ 이상의 건조물을 말한다(15). 초콜릿의 주요 원료인 카카오에는 활성산소 생성을 억제하는 기능을 가진 폴리페놀 성분이 함유되어 있어 면역력을 키워주고, 산화 스트레스를 감소시킴으로써 노화방지에도 효과가 있다고 알려져 있다. 더불어 최근에는 코코아의 산화 방지 효과가 녹차나 포도주보다 높다고 보고되었다(16). 이러한 초콜릿 의 효능과 초콜렛을 구성하고 있는 성분과의 관계성에 대해 서는, 심혈관계 질환 및 면역 체계와 초콜릿의 기능성 및 유효 성분간의 관계(17), 초콜릿에서의 항산화 활성과 procyanidin 및 catechine의 함량에 관한 연구 $(18,19)$, 초콜릿 의 항산화 활성과 폴리페놀 함량에 대한 연구(20) 등이 수행 되었다. 이 밖에도 초콜릿에 부가적인 건강 기능성을 증진 시키기 위한 연구가 이루어졌으며(21-23), 특히 초콜릿에 유산균을 배양하는 함으로써 초콜릿을 probiotics 운반체로 활용하고 그 효과를 더하는 연구가 보고되었다(24-26). 한 편, 초콜릿과 초콜릿 과자류를 포함한 국내 초콜릿 시장은 매년 10 15\%의 증가세를 보이고 있으며, 최근 초콜릿 제품 은 소포장화, 고급화 등 프리미엄 초콜릿의 강세가 두드러 지는 경향을 나타나고 있다(27). 더불어 기성 제품보다는 건강을 생각하고 다양한 부재료의 첨가로 새로운 초콜릿 맛을 즐기려는 소비자가 늘고 있으며(27) 이러한 트렌드를 반영한 제품군 개발이 요구되고 있다.

이에 본 연구에서는 증가하는 초콜릿의 소비 수요 및 트렌드에 발맞춰 초콜릿의 식품영양학적 가치를 유지하는
새로운 제품군 중 하나로, 유산균에 의한 초콜릿 발효 제품 개발을 위한 기초자료를 제공하고자 하였다.

\section{재료 및 방법}

\section{실험재료 및 시약}

본 실험에 사용된 초콜릿은 (주)제키스(Jekiss Co., Ltd., Jeju)의 고유 레시피를 바탕으로 제조된 것으로, 설탕 $10 \%$, 코코아 분말 $20 \%$, 리얼 초콜릿 $0.3 \%$, 감귤농축액 $6.7 \%$, 정제수 $63 \%$ 를 포함하도록 제조하였다. Folin-Ciocalteu's reagent, gallic acid, rutin, 2,2-diphenyl-1-picrylhydraxyl (DPPH), 2,2'-azino-bis(3-ethylbenzothiazoline-6-sulfonic acid) diammonium salt(ABTS), 2,2'-azobis(2-methylpropionamidine) dihydrochloride(AAPH), a-(4-pyridyl-1-oxide)-N-tert-butylnitrone (4-POBN), theobromine, caffeine은 Sigma Chemical Co.(St. Louis, MO, USA)에서 구입하였으며, Lactobacilli MRS Broth는 Difco Laboratories(Detroit, MI, USA)에서 구입하여 사용하였다.

\section{사용 균주 및 배지}

실험에 사용한 균주인 Lactobacillus plantarum CK10은 경기대학교 식품생물공학과 이종훈 교수로부터 제공받았 다(28). L plantarum CK10 균주는 발효에 사용되기 전 MRS 배지에서 2회 계대 배양한 후 $600 \mathrm{~nm}$ 파장에서 $\mathrm{OD}$ 값이 2.0 일 때 $(9.94 \log \mathrm{CFU} / \mathrm{mL})$ 사용하였다.

\section{초콜릿 발효물 제조}

초콜릿 발효물은 일련의 과정 통해 제조하였다. 간단히 설명하면, (주)제키스 고유의 레시피를 바탕으로 원료들을 발효기(NYM-531KC, NUC Co., Ltd., Daegu, Korea)에서 배합한 후 $85^{\circ} \mathrm{C}$ water bath에서 30 분간 살균하였다. 살균이 끝나면, 발효기를 $44^{\circ} \mathrm{C}$ 로 세팅하고 초콜릿 준비액이 $44^{\circ} \mathrm{C}$ 로 식도록 방치하였다. 초콜릿 준비액이 충분히 식으면 $\mathrm{OD}$ 값 이 2.0 이 되도록 자란 L. plantarum CK10을 배합량 대비 $3 \%(\mathrm{~g} / \mathrm{g})$ 으로 접종하여 발효시켰다. 발효가 진행되면 시간 대별로 $\mathrm{pH}$ 및 산도를 측정하였으며, 각 시간대별 시료 50 $\mathrm{g}$ 을 취해 증류수 $50 \mathrm{~g}$ 을 첨가하여 2 배 희석하고 급속동결고 $\left(-50^{\circ} \mathrm{C}\right)$ 에 보관하였다. 보관된 시료는 동결 건조를 통해 분 말화한 후 차후 실험에 사용하였다. 각 시간대별 초콜릿 발효물은 발효 시간에 따라 발효하지 않은 대조구, 발효 $2,4,8,24$, 그리고 32 시간으로 나타내었다.

\section{초콜릿 발효물 전처리}

앞선 연구들을 바탕으로(29-32) 동결 건조된 초콜릿 발효 물은 지방을 제거하고 실험에 사용하였다. 지방을 제거하 기 위해, 동결 건조하여 분말화 된 시료 $5 \mathrm{~g}$ 에 대하여 5 
$\mathrm{mL} n$-hexane을 첨가한 후 5 분간 초음파 추출하였다. 추출이 끝나면 $4{ }^{\circ} \mathrm{C}, 1,000 \times \mathrm{g}$ 의 조건으로 10 분 간 원심분리 한 후 상층액을 덜어냄으로써 지방을 제거하였다. 지방이 제거된 시료는 항산화 실험을 위하여 acetone : distilled water $=$ $7: 3$ 의 용액 $5 \mathrm{~mL}$ 을 첨가하고 10 분간 초음파 추출하였다. $4{ }^{\circ} \mathrm{C}, 1,000 \times \mathrm{g}$ 의 조건으로 10 분간 원심분리 한 후 잘 녹아난 상층액을 얻고 이 것을 $100 \mathrm{mg} / \mathrm{mL}$ 로 하여 실험에 사용하였다.

\section{$\mathrm{pH}$ 및 적정산도 측정}

발효를 진행하며 발효 시간대별로 $\mathrm{pH}$ 및 적정산도를 측 정하였다. $\mathrm{pH}$ 는 초콜릿 발효물에 대하여 시간대별로 $\mathrm{pH}$ meter(Thermo Scientific Inc., Waltham, MA, USA)로 측정하 였다. 적정산도(Total Titratable Acidity, TTA)는 $5 \mathrm{~g}$ 의 초콜 릿 발효물을 $\mathrm{pH} 8.5$ 로 적정하는데 필요한 $0.1 \mathrm{~N} \mathrm{NaOH}$ 의 양을 측정함으로써 계산하였다.

\section{총 폴리페놀 함량 및 총 플라보노이드 함량 측정}

총 폴리페놀 함량은 Cheung 등(33)의 방법을 약간 변형하 여 수행하였다. 간단하게 기술하면, 증류수 $1.375 \mathrm{~mL}$ 에 $0.125 \mathrm{~mL}$ 의 시료를 넣은 후 $0.5 \mathrm{~mL}$ Folin-Ciocalteu's 시약을 넣고 3 분 후에 $1 \mathrm{~mL}$ 의 $\mathrm{Na}_{2} \mathrm{CO}_{3}$ 를 가한 다음 실온에서 30 분 동안 정치 반응시켰다. 30 분이 지나면 분광광도계(Sunrise, Tecan, Salzburg, Austria)를 이용하여 $700 \mathrm{~nm}$ 에서 흡광도를 측정하고 계산하였으며, 함량은 gallic acid equivalents $(\mathrm{mg}$ $\mathrm{GAE} / \mathrm{g}$ )로 나타내었다. 총 플라보노이드 함량은 Zhishen 등 (34)의 방법을 변형하여 측정하였다. 시료 $40 \mu \mathrm{L}$ 에 $5 \%$ $\mathrm{NaNO}_{2} 6 \mu \mathrm{L}$ 를 첨가하여 5 분간 반응시킨 후 $10 \% \mathrm{AlCl}_{3}$ $12 \mu \mathrm{L}$ 를 혼합하여 6 분간 반응시킨 다음 $1 \mathrm{~N} \mathrm{NaOH} 40 \mu \mathrm{L}$ 를 첨가한 후 분광광도계(Sunrise, Tecan, Salzburg, Austria)를 이용하여 $510 \mathrm{~nm}$ 에서 흡광도를 측정하였다. 함량은 rutin equivalents(mg RE/g)로 나타내었다.

\section{$\mathrm{DPPH}$ 라디칼 소거능 측정}

$\mathrm{DPPH}$ 라디칼 소거능은 이전에 보고된 방법 $(35,36)$ 을 토 대로 수행하였다. DPPH을 에탄올에 용해시켜 $200 \mu \mathrm{M}$ DPPH 용액을 실험에 사용하였다. 96 well plate에 시료를 농도별로 $40 \mu \mathrm{L}$ 씩 분주하고 $200 \mu \mathrm{M} \mathrm{DPPH}$ 용액 $160 \mu \mathrm{L}$ 를 첨가한 후 30 분간 $37^{\circ} \mathrm{C}$ 의 암소에서 반응시켰다. 30 분 후 반응이 끝나면 분광광도계(Sunrise, Tecan)를 이용하여 517 $\mathrm{nm}$ 에서 흡광도를 측정하고 소거능을 계산하였다. Catechin 을 양성대조구로 사용하였다.

\section{$\mathrm{ABTS}$ 라디칼 소거능 측정}

초콜릿 발효물의 $\mathrm{ABTS}$ 라디칼 소거능은 이 전에 보고된 방법(37)을 일부 변형하여 수행하였다. ABTS 용액은 $7 \mathrm{mM}$ $\mathrm{ABTS}$ 와 $2.45 \mathrm{mM} \mathrm{K}_{2} \mathrm{~S}_{2} \mathrm{O}_{8}$ 를 혼합해 16 시간 동안 암조건에 보관하였다. 16 시간 후 $\mathrm{ABTS}$ 용액은 $\mathrm{OD}$ 값이 $0.700 \pm 0.005$ 이 되도록 증류수로 희석하여 사용하였다. 큐벳에 ABTS
용액 $900 \mu \mathrm{L}$ 과 시료 $100 \mu \mathrm{L}$ 을 혼합하여 실온에서 2분간 반응시킨 후, 분광광도계(UV1800, Shimadzu., Kyoto, Japan)를 이용하여 $734 \mathrm{~nm}$ 에서 흡광도를 측정함으로써 소 거능을 계산하였다. 양성대조군으로 a-tocopherol을 사용하 였다.

\section{ESR을 이용한 alkyl 라디칼 소거능 측정}

Alkyl 라디칼 소거능은 기존에 보고된 논문들을 참고하 여 측정하였다(38-40). $20 \mu \mathrm{L}$ distilled water, $40 \mathrm{mM} \mathrm{AAPH}$, $40 \mathrm{mM}$ 4-POBN과 시료를 각각 $20 \mu \mathrm{L}$ 씩 순서대로 첨가하여 $37^{\circ} \mathrm{C}$ 항온수조에서 30 분간 반응시켰다. 반응이 끝나면 capillary tube로 옮겨 끝을 잘 막아 준 후, electron spin resonance(ESR) spectrometer(JES-FA200, JEOL, Tokyo, Japan)로 측정하였다. 측정조건은 magnetic field 336.000 $\mathrm{mT}$, power $7 \mathrm{mM}$, sweep time $30 \mathrm{sec}$, sweep width $10 \mathrm{mT}$, frequency $9.43 \mathrm{GHz}$, modulation width $0.2 \mathrm{mT}$, amplitude 500 , time constant $0.03 \mathrm{sec}$ 으로 설정하였다. 양성 대조군으 로 catechin이 사용되었다.

\section{Gas chromatography-Mass(GC- MS) 분석}

Gas chromatography 분석은 제주대학교 공동실험실습관 에 보유중인 GC-MS(QP-2010, Shimadzu Co., Kyoto, Japan) 을 사용하여 수행하였다. GC-MS 분석을 위해, 오븐 온도는 $60^{\circ} \mathrm{C}$ 에서 3 분간 유지하고 분당 $3^{\circ} \mathrm{C}$ 씩 승온하여 $90^{\circ} \mathrm{C}$ 에서 1 분간 유지하였고, 다시 분당 $4^{\circ} \mathrm{C}$ 씩 승온하여 $130^{\circ} \mathrm{C}$ 에서 1 분간 유지하였다. 이 후, 분당 $10^{\circ} \mathrm{C}$ 씩 $180^{\circ} \mathrm{C}$ 까지 승온하고, 분당 $5^{\circ} \mathrm{C}$ 씩 $210^{\circ} \mathrm{C}$ 까지 승온하여 2 분간 유지한 후, 분당 $10^{\circ} \mathrm{C}$ 씩 승온하여 $300^{\circ} \mathrm{C}$ 에서 3 분간 유지함으로써 분석을 마무리 하였다. GC 컬럼은 Rtx- 5MS(30 m length, $0.25 \mu \mathrm{m}$ diameter, $0.25 \mu \mathrm{m}$ thickness)를 사용하였다. 운반 가스는 헬륨을 사용 하였으며, total flow는 $1 \mathrm{~mL} / \mathrm{min}$ 으로 분석을 진행하였다. 시료 주입 온도는 $250^{\circ} \mathrm{C}$, transfer 온도는 $280^{\circ} \mathrm{C}$ 로 설정하였 으며, scan mode로 $40 ~ 800 \mathrm{~m} / \mathrm{z}$ 범위에서 분석하였다. $\mathrm{GC}-\mathrm{MS}$ 분석을 통하여 검출된 피크의 화합물 동정은 Willey 9 library database를 이용하여 수행하였고, library와 유사도가 $85 \%$ 이상인 화합물만 동정하였다. 동정된 화합물 의 성분조성비는 피크의 intensity를 기준으로 전체 피크에 서 각 피크가 차지하는 비율을 기반으로 산출하였다.

\section{High performance liquid chromatography-Mass} 분석

초콜릿 발효산물에서의 theobromine과 caffeine에 대한 정량 분석은 Shimadzu prominence UFLC(Shimadzu Co., Kyoto, Japan)를 이용하여 수행하였다. 검출기로는 SPD20A UV detector(Shimadzu Co., Kyoto, Japan), 컬럼은 Shim-pack GIS $(250 \times 4.6 \mathrm{~mm}, 5$ um ODS, Shimadzu Co., Kyoto, Japan)을 사용하였다. 검출 파장은 UV $271 \mathrm{~nm}$, 이동 
상은 $15 \mathrm{mM}$ Potassium phosphate in water(pH 3.50 \pm 0.05 , adjusted with phsphoric acid) : Acetonitrile $=83: 17(\mathrm{v} / \mathrm{v})$ 인 용액을 이용하였으며, 유속은 $1.0 \mathrm{~mL} / \mathrm{min}$, 시료 주입량은 $20 \mu \mathrm{L}$ 로 하여 분석하였다.

\section{표준 검량선 작성}

Theobromine 표준품과 caffeine 표준품을 $15 \mathrm{mM}$ potassium phosphate in water에 녹여 각각 $500 \mu \mathrm{g} / \mathrm{mL}$ 의 표준 용액을 만들고, 이를 다시 $15 \mathrm{mM}$ potassium phosphate를 이용하여 희석함으로써 사용하였다. Theobromine은 $20,50,200,400$ $\mu \mathrm{g} / \mathrm{mL}$ 의 농도로, caffeine은 $5,1050,100 \mu \mathrm{g} / \mathrm{mL}$ 의 농도로 희석하였으며, 각 용액 $20 \mu \mathrm{L}$ 를 HPLC에 주입하여 나타난 chromatogram 상의 peak 면적을 기준으로 표준 검량선을 작성하였다.

\section{통계처리}

실험은 3회 반복 수행하여 평균치와 표준편차로 나타냈 고, 유의성 검증은 SPSS(SPSS Inc., Chicago, IL, USA)를 이용하여 ANOVA one way로 수행하였다.

\section{결과 및 고찰}

\section{$\mathrm{pH}$ 및 적정산도 측정}

L. plantarum CK10에 의한 초콜릿 발효에서 시간에 따른 $\mathrm{pH}$ 및 적정산도를 측정한 값은 Fig. 1에 나타내었다. 발효를 진행하며 $\mathrm{pH}$ 및 적정산도를 측정한 결과, 초콜릿 발효 4시 간까지 $\mathrm{pH}$ 가 점차 감소하고 적정산도가 점차 증가하는 것 을 확인하였다. 4 시간이 지난 이후 24 시간까지 그 증감의 폭이 급격히 증가하였으며, 24시간 이후 다시 증감 폭이 작아진 것을 확인할 수 있었다. 이를 토대로 L plantarum

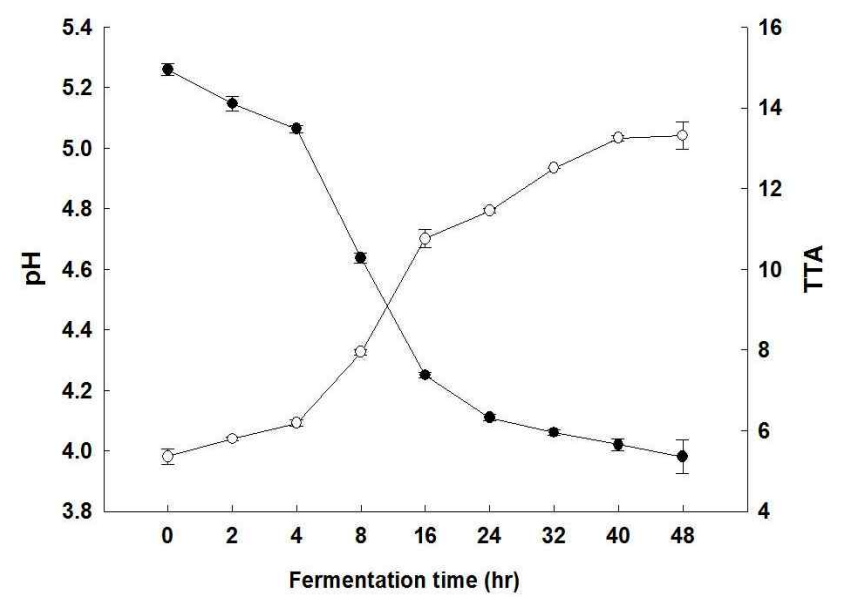

Fig. 1. Changes in $\mathrm{pH}$ and titratable acidity of chocolates through the fermentation for $48 \mathrm{hr}$.

-, $\mathrm{pH} ;$ - -, TTA. Values are mean $\pm \mathrm{SD}(\mathrm{n}=3)$.
CK10에 의한 초콜릿의 발효는 4시간과 24시간 사이에서 가장 활발하게 일어나고, 이후 일정한 수준으로 유지되는 것을 예상할 수 있다.

\section{총 폴리페놀 함량, 총 플라보노이드 함량}

L. plantarum $\mathrm{CK} 10$ 에 의한 발효 초콜릿의 총 폴리페놀 함량과 총 플라보노이드 함량은 Table 1과 같다. 발효하지 않은 초콜릿 대비해서 발효 8시간에서 유의적 수준의 폴리 페놀 증가를 확인할 수 있었다( $\mathrm{p}<0.05$; Control, 5.47 \pm 0.36 $\mathrm{mg} \mathrm{GAE} / \mathrm{g}$; 8시간, $6.34 \pm 0.12 \mathrm{mg} \mathrm{GAE} / \mathrm{g}$ ). 발효 24시간에서 발효 8시간 대비 그 함량이 유의적 수준으로 약간 감소하였 으나(p<0.05; 8시간, $6.34 \pm 0.12 \mathrm{mg} \mathrm{GAE} / \mathrm{g} ; 24$ 시간, $5.19 \pm$ $0.23 \mathrm{mg} \mathrm{GAE} / \mathrm{g}$ ), 발효하지 않은 초콜릿과 비교하였을 때는 서로 유사한 수준의 함량임을 확인할 수 있었다 $(\mathrm{p}>0.05$; control, $5.47 \pm 0.36 \mathrm{mg} \mathrm{GAE} / \mathrm{g} ; 24$ 시간, $5.19 \pm 0.23 \mathrm{mg}$ $\mathrm{GAE} / \mathrm{g}$ ). 발효 24시간에서 확인된 폴리페놀 함량은 발효 32 시간까지 유지되는 것으로 여겨진다. 총 플라보노이드 함량은 발효 후 32 시간까지 유의적 수준의 변화 없이 일정 하게 유지되는 것으로 확인되었다.

Table 1. Total polyphenol and total flavonoid contents of fermented chocolates

\begin{tabular}{ccc}
\hline Fermentation time (hr) & $\begin{array}{c}\text { Total polyphenol } \\
\left(\mathrm{mg} \mathrm{GAE}^{1} / \mathrm{g}\right)\end{array}$ & $\begin{array}{c}\text { Total flavonoid } \\
\left(\mathrm{mg} \mathrm{RE}^{2} / \mathrm{g}\right)\end{array}$ \\
\hline 0 & $5.47 \pm 0.36^{3)}$ & $3.23 \pm 0.30$ \\
2 & $5.25 \pm 0.13$ & $3.06 \pm 0.36$ \\
4 & $5.69 \pm 0.33$ & $3.46 \pm 0.62$ \\
8 & $6.34 \pm 0.12^{* 4)}$ & $3.53 \pm 0.34$ \\
24 & $5.19 \pm 0.23$ & $3.56 \pm 0.23$ \\
32 & $5.38 \pm 0.09$ & $3.39 \pm 0.33$ \\
\hline
\end{tabular}

${ }^{1)} \mathrm{GAE}$, gallic acid equivalent.

${ }^{2} \mathrm{RE}$, rutin equivalent.

${ }^{3)}$ Values are Mean $\pm \mathrm{SD}(\mathrm{n}=3)$.

${ }^{4)}$ The statistically significant differences are presented as ${ }^{*}<0.05$.

\section{$\mathrm{DPPH}$ 라디칼 소거능}

$\mathrm{DPPH}$ 라디칼은 짙은 보라색의 비교적 안정한 자유 라디 칼로서, ascorbic acid나 BHA와 같은 항산화 물질에 의해 환원되어 노란색으로 탈색되는 특징을 갖는다. 많은 연구 에서는 이러한 특징을 토대로 DPPH 라디칼 소거능을 천연 물질의 항산화능을 평가하기 위한 지표로서 활용하고 있다 (2). L plantarum $\mathrm{CK} 10$ 에 의한 초콜릿 발효에 따른 $\mathrm{DPPH}$ 라디칼 소거능은 Fig. 2에 나타내었다. 발효하지 않은 초콜 릿과 발효 시간대별 초콜릿 산물에 대하여 $\mathrm{DPPH}$ 라디칼 소거능을 측정한 결과, 발효 전 $46.90 \% \pm 4.59$ 의 소거능을 보이는 초콜릿은 발효 2 시간이 지났을 때 $44.54 \% \pm 5.95$, 발효 4시간이 지났을 때 $52.48 \% \pm 6.32$, 발효 8 시간이 지났을 
때 $56.04 \% \pm 4.01$, 발효 24 시간이 지났을 때 $42.09 \% \pm 6.84$, 발효 32시간이 지났을 때 $47.17 \% \pm 2.18$ 로 확인되었다. 발효 8시간에서 일부 증가하였던 DPPH 라디칼 소거능이 발효 24 시간에서 유의적으로 감소하였는데( $\mathrm{p}<0.05,8$ 시간, $56.04 \%$ $\pm 4.01 ; 24$ 시간, $42.09 \% \pm 6.84$ ), 이러한 배양 시간에 따른 $\mathrm{DPPH}$ 라디칼 소거능의 증감은 총 폴리페놀 함량의 증감 양상과 일치한다. 이는 항산화 작용과 폴리페놀의 함량의 상관관계에 관한 여러 연구에서(41,42) 보고된 바와 유사한 결과이며, 따라서 발효 초콜릿의 DPPH 라디칼 소거능는 폴리페놀 함량 변화에 기인한 것으로 추정할 수 있다. 발효 하지 않은 초콜릿과 모든 시간대별 발효 산물을 비교하였을 때, DPPH 라디칼 소거능에 대한 유의적 수준의 변화는 없었으며( $\mathrm{p}>0.05)$, 이를 통해 초콜릿의 뛰어난 DPPH 라디 칼 소거능이 발효 후에도 유지되는 것을 확인하였다.

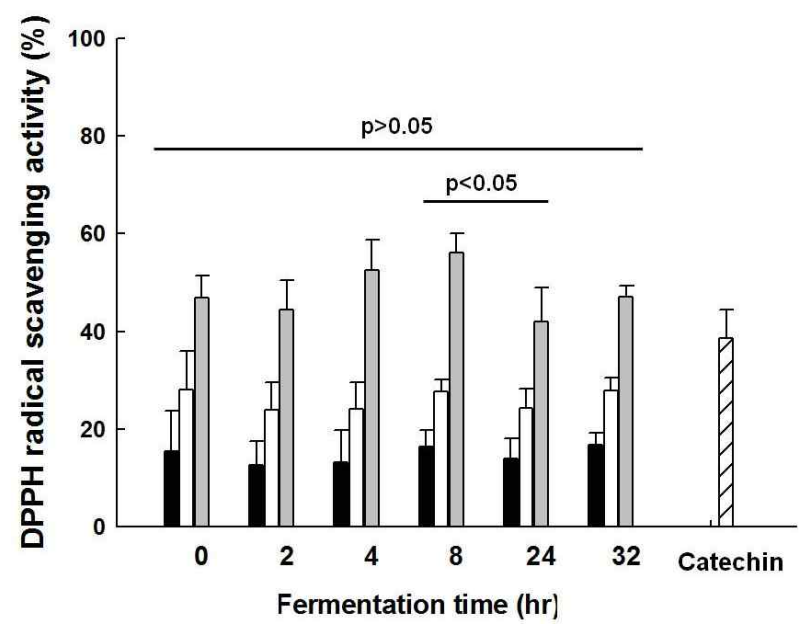

Fig. 2. DPPH radical scavenging activity of chocolates fermented by $L$. plantarum CK10.

$\square, 200 \mu \mathrm{g} / \mathrm{mL} ; \square, 400 \mu \mathrm{g} / \mathrm{mL} ; \square, 800 \mu \mathrm{g} / \mathrm{mL} ; \square, 100 \mu \mathrm{M}$. The appropriate amount of catechin was used as a positive control. Values are Mean \pm SD ( $n=3$ ).

\section{ABTS 라디칼 소거능}

L. plantarum $\mathrm{CK} 10$ 에 의한 초콜릿 발효에 따른 $\mathrm{ABTS}$ 라디칼 소거능은 Fig. 3에 나타내었다. 앞선 DPPH 라디칼 소거능과 유사하게 발효 8 시간 대비 발효 24시간에서 유의 적 수준의 $\mathrm{ABTS}$ 라디칼 소거능 감소가 확인되었다( $<0.05$; 8시간, $63.53 \% \pm 3.71 ; 24$ 시간, $53.24 \% \pm 2.33$ ). 그러나 발효하 지 않은 초콜릿인 control과 두 시간대의 발효 산물을 각각 비교하면, $\mathrm{ABTS}$ 라디칼 소거능에 대하여 유의적 차이가 없는 것으로 확인되었다(p>0.05; Contorl, $57.89 \% \pm 3.35 ; 8$ 시 간, $63.53 \% \pm 3.71 ; 24$ 시간, $53.24 \% \pm 2.33$ ), 이를 통해 초콜릿 의 항산화 활성이 매우 뛰어남을 다시 한 번 확인할 수 있었으며, 발효된 초콜릿은 기존 초콜릿의 우수한 항산화 활성을 유지하는 것으로 여겨진다.

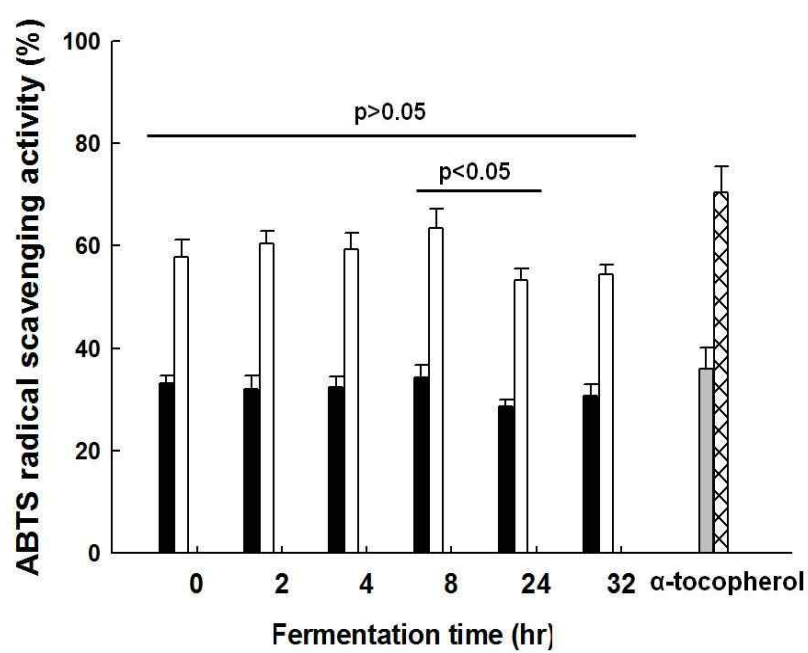

Fig. 3. ABTS radical scavenging activity of chocolates fermented by $L$. plantarum $\mathrm{CK} 10$.

, $200 \mu \mathrm{g} / \mathrm{mL} ; \square, 400 \mu \mathrm{g} / \mathrm{mL} ; \square, 100 \mu \mathrm{M} ; \square \nabla, 200 \mu \mathrm{M}$. The appropriate amount of a-tocopherol was used as a positive control. Values are Mean $\pm \mathrm{SD}(\mathrm{n}=3)$.

\section{Alkyl 라디칼 소거능}

L. plantarum CK10에 의한 발효 초콜릿의 Alkyl 라디칼 소거능은 Fig. 4 와 같다. 발효 전 $61.48 \% \pm 11.18$ 의 소거능을 보이는 초콜릿에 대하여 2시간 발효를 진행하였을 때 $57.44 \% \pm 7.94,4$ 시간 발효를 진행하였을 때 $56.36 \% \pm 12.90$, 8시간 발효를 진행하였을 때 $65.77 \% \pm 7.77,24$ 시간 발효를 진행하였을 때 $61.67 \% \pm 6.85,32$ 시간 발효를 진행하였을 때 $63.63 \% \pm 4.62$ 의 소거능을 측정할 수 있었다. 앞선 다른 종류의 라디칼들과 마찬가지로 발효 후에도 초콜릿의 우수 한 라디칼 소거능이 유지되고 있음을 확인하였다.

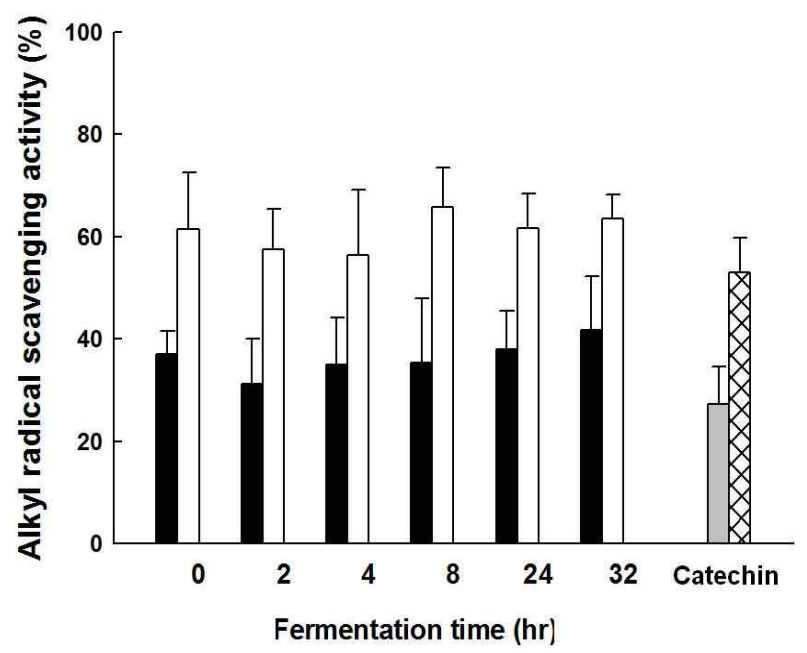

Fig. 4. Alkyl radical scavenging activity of chocolates fermented by L. plantarum CK 10.

, $150 \mu \mathrm{g} / \mathrm{mL} ; \square, 300 \mu \mathrm{g} / \mathrm{mL} ; \square, 10 \mu \mathrm{M} ; \varangle, 20 \mu \mathrm{M}$. The appropriate amount of catechin was used as a positive control. Values are Mean \pm SD ( $n=3)$. 
Gas chromatography-mass spectrum과 High-performance liquid chromatography를 이용한 성분 분석

$L$ plantarum $\mathrm{CK} 10$ 에 의한 초콜릿 발효에 따른 성분 조성 의 변화는 Table 2과 같다. 발효가 진행됨에 따라 젖산균의 대표적인 발효 산물인 Lactic acid의 peak 면적 \%가 증가하 는 것을 확인하였다. 시료에 대하여 높은 함량을 보이는 성분으로는 $\mathrm{HMF}$ (Hydroxymethylfurfural), xanthosine, caffeine, theobromine 등이 검출되었다. HMF는 식품 가공 중에 발생 하는 갈변을 측정하는 지표로 사용되는 물질로 많은 가공 식품들에서 검출되는 성분이다 $(43,44)$. Theobromine과 caffeine은 xanthine 유도체인 methylxanthine 중 하나로서 초콜릿의 원료인 Theobroma cacao를 구성하고 있는 alkaloid의 $99 \%$ 를 차지하고 있으며, cacao의 쓴맛에 기여한 다고 알려져 있다(45). 특히 theobromine은 Theobroma cacao의 대표적인 물질로 손꼽힌다. Theobromine과 caffeine은 신경계의 흥분을 유도함으로써 여러 생리적 작 용을 일으키는데, 심근과 골격근의 흥분을 통한 강심작용, 위액 분비 촉진, 이뇨 작용 등이 보고되어 있다(46-48). GC-MS 분석 결과로 Table 2에 나타난 바와 같이 초콜릿의 대표적인 구성 성분인 theobromine과 caffeine, theobromine 의 전구체인 xanthosine에 대한 상대적인 성분비가 발효가 진행됨에 따라 변화하고 있으므로, HPLC를 이용하여 theobromine과 caffeine에 대한 정량 분석을 수행하였다. $\mathrm{HPLC}$ 를 이용한 theobromine과 caffeine의 정량 분석 결과,

Table 2. Compounds identified from fermented chocolates by using GC-MS

\begin{tabular}{|c|c|c|c|c|c|c|}
\hline \multirow{3}{*}{ Compounds } & \multicolumn{6}{|c|}{ Fermentation time (hr) } \\
\hline & 0 & 2 & 4 & 8 & 24 & 32 \\
\hline & \multicolumn{6}{|c|}{ Area $\%$} \\
\hline 2-Fluoro-2-methylpropane & 0.34 & 0.28 & 0.24 & 0.16 & - & 0.09 \\
\hline 2-Butan-2-ylsulfanylbutane & 1.11 & 1.02 & 0.96 & 0.86 & 0.29 & 0.25 \\
\hline Diacetone alcohol & 2.59 & 2.34 & 2.34 & 2.18 & 1.11 & 1.21 \\
\hline 2-Furanmethanol & 1.05 & 0.86 & 0.89 & 1.08 & 0.42 & 0.38 \\
\hline 1,4-Dioxane-2,3-diol & - & 1.24 & 1.21 & 1.10 & - & 0.46 \\
\hline 1,2,3-Propanetriol & 1.42 & 0.68 & 0.61 & 0.57 & 0.47 & - \\
\hline $\mathrm{N}, \mathrm{N}-\mathrm{Bis}(2$-methoxyethyl)methylamine & 1.97 & 1.41 & 2.23 & - & 2.63 & 2.25 \\
\hline Lactic acid & - & - & - & - & 13.36 & 14.88 \\
\hline 2(5H)-Furanone & 0.42 & 0.26 & 0.27 & 0.28 & 0.31 & 0.27 \\
\hline 1,2-Cyclopentanedione & 1.62 & 1.44 & 1.30 & 1.32 & 0.78 & 0.70 \\
\hline 3-Methyl-2,5-furandione & - & - & - & 0.19 & 0.19 & 0.13 \\
\hline Allyl formate & 0.89 & 0.75 & 0.74 & 0.79 & 0.77 & 0.61 \\
\hline 2H-pyran-2,6(3H)-dione & 0.52 & 0.51 & 0.48 & 0.45 & 0.34 & 0.31 \\
\hline Dimethyl-ester-hydroxy-propanedioic acid & 0.53 & 0.25 & 0.20 & 0.20 & - & - \\
\hline 2,5-Dimethyl-4-hydroxy-3(2H)-furanone & 0.55 & 0.39 & 0.25 & 0.52 & 0.45 & 0.39 \\
\hline 5-Methyl-2,4(1H,3H)-pyrimidinedione & 3.29 & 7.25 & 1.81 & 2.54 & 3.59 & 3.15 \\
\hline 3-Buten-2-ol & - & - & - & - & 0.46 & 0.25 \\
\hline N-Ethyl-N-nitroso-ethanamine & 0.60 & 0.55 & 0.53 & 0.75 & 0.37 & 0.29 \\
\hline 3-Hydroxy-2,3-dihydromaltol & 1.44 & 1.37 & 1.46 & 1.80 & 0.74 & 0.61 \\
\hline Benzoic acid & - & - & - & - & 0.18 & 0.10 \\
\hline 5-Hydroxymaltol & 1.05 & 0.91 & 0.93 & 0.95 & 0.75 & 0.58 \\
\hline 1,2-Benzenediol & - & - & - & - & 0.53 & 0.45 \\
\hline $\mathrm{HMF}$ & 23.27 & 20.91 & 19.23 & 20.02 & 11.15 & 9.14 \\
\hline Xanthosine & 6.44 & 8.61 & 8.29 & 9.40 & 19.16 & 22.74 \\
\hline Caffeine & 14.34 & 12.44 & 12.96 & 12.91 & 9.20 & 9.04 \\
\hline Theobromine & 15.66 & 11.55 & 14.87 & 16.16 & 20.14 & 20.03 \\
\hline Pentadecanoic acid & 0.28 & 0.44 & 0.59 & 0.46 & 2.38 & 2.62 \\
\hline (Z)-9-Octadecenoic acid & - & - & - & - & 0.39 & 0.57 \\
\hline
\end{tabular}


발효가 진행됨에 따라 유의적인 차이 없이 해당 성분들의 함량이 유지됨을 확인하였다(Table 3). Table 2 의 GC 분석 결과와 HPLC 결과를 종합적으로 살펴보았을 때, 발효가 진행됨에 따라 theobromine과 caffeine의 상대적인 성분비 는 변화하였으나, 정량적인 변화는 크게 나타나지 않았으 므로, 두 성분을 제외한 다른 물질들의 정량적 변화가 예상 되며 이에 대한 추가적인 연구가 필요하다고 사료된다.

본 연구에서는 L plantarum CK10에 의한 초콜릿의 젖산 발효 가능성과 발효가 진행됨에 따른 항산화 활성과 함유 성분에 대한 영향을 분석하였다. 발효 초콜릿은 발효로 인 해 생기는 특유의 산미와 풍미를 바탕으로 새로운 제품군으 로 개발될 수 있으며, 이를 통해 초콜릿 산업의 다양화에 기여할 수 있을 것이라고 판단된다. 다양한 발효 식품에 대한 항염증(49-52), 항당뇨 $(53,54)$ 활성 연구 결과들에 주 목하여, 발효 초콜릿의 항산화 활성뿐만 아니라 다양한 활 성 변화에 대한 탐색과 기능성에 대한 추가적인 연구가 필요하며, 이러한 추가적인 연구를 통해 발효 초콜릿의 새 로운 수요 창출 및 부가가치를 높일 수 있을 것으로 사료 된다.

Table 3. Theobromine and caffeine levels in fermented chocolates

\begin{tabular}{ccc}
\hline $\begin{array}{c}\text { Fermentation time } \\
(\mathrm{hr})\end{array}$ & $\begin{array}{c}\text { Theobromine } \\
(\mathrm{mg} / \mathrm{g})\end{array}$ & $\begin{array}{c}\text { Caffeine } \\
(\mathrm{mg} / \mathrm{g})\end{array}$ \\
\hline 0 & $6.16 \pm 0.77^{1)}$ & $1.99 \pm 0.22$ \\
2 & $6.69 \pm 1.99$ & $2.10 \pm 0.35$ \\
4 & $6.47 \pm 2.36$ & $2.05 \pm 0.45$ \\
8 & $6.50 \pm 1.34$ & $2.08 \pm 0.22$ \\
24 & $4.30 \pm 2.74$ & $1.43 \pm 0.58$ \\
32 & $6.45 \pm 1.54$ & $2.07 \pm 0.23$ \\
\hline
\end{tabular}

${ }^{1)}$ Values are Mean $\pm \mathrm{SD}(\mathrm{n}=3)$.

\section{요 약}

Lactobacillus plantarum CK10을 활용하여 초콜릿 발효 를 수행하고 발효산물의 항산화 활성 및 성분 변화를 측정 하였다. 초콜릿 발효 산물의 $\mathrm{pH}$ 는 발효 시간이 지남에 따라 감소하고 적정산도는 증가했으며, 그 증감의 폭은 발효 4시 간과 24시간에서 가장 급격히 나타났다. 폴리페놀 함량은 발효 산물의 생성이 활발히 일어나고 있을 것으로 예상되는 발효 8시간에서 약간 증가하였으나 대체로 발효 전후 간 유사한 함량이 확인되었으며, 플라보노이드 함량 또한 발 효 전후가 유사하게 유지되었다. 항산화 활성의 지표로 $\mathrm{DPPH}$ 라디칼, ABTS 라디칼, Alkyl 라디칼에 대한 소거능 을 측정하였을 때, 발효가 진행되어도 초콜릿의 우수한 라 디칼 소거능이 유지됨을 확인하였다. GC-MS에 의한 성분 분석을 수행하였을 때, 발효 시간이 지남에 따라 lactic acid
의 성분비가 증가하는 것을 확인하였다. 더불어 $\mathrm{HMF}$, xanthosine, caffeine, theobromine 등의 물질이 주요 성분으 로 검출되었다. High-performance liquid-chromatography을 이용하여 정량 분석을 수행했을 때, 발효에 따른 theobromine과 caffeine의 함량 변화는 크게 관찰되지 않 았다.

\section{감사의 글}

본 연구는 산업통상자원부에서 시행한 2015년 지역주력 산업육성(R\&D)의 연구 결과입니다.

\section{References}

1. Park KY (2012) Increased health functionality of fermented foods. Food Industry and Nutrition, 17, 1-8

2. Jun DH, Cho WA, Lee JB, Jang MJ, You MS, Park JY, Kim SH and Lee JT (2014) Antioxidant Activity of Chestnut (Castanea crenata S. et Z.) bur Fermented by Lactobacillus casei. J Life Sci, 24, 1193-1199

3. Song HS, Kim HK, Min HO, Choi JD, Kim YM (2011) Changes in physicochemical and sensory properties of Hizikia fusiforme water extract by fermentation of lactic acid bacteria. Kor J Fish Aquat Sci, 44, 104-110

4. Choi MS, Kim DM, Oh KH (2015) Studies on the enhanced physiological activities of mixed lactic acid bacteria isolated from fermented watery kimchi, Dongchimi. KSBB, 30, 245-252

5. Jeon JM, Choi SK, Kim YJ, Jang SJ, Cheon JW, Lee HS (2011) Antioxidant and antiaging effect of ginseng berry extract fermented by lactic acid bacteria. J Soc Cosmet Sci Korea, 37, 75-81

6. Jung HK, Kim ER, Yae HS, Choi SJ, Jung JY, Juhn SL (2000) Cholesterol-lowering effect of lactic acid bacteria and fermented milks as probiotic functional foods. Food Industry and Nutrition, 5, 29-35

7. Yeo MH, Kim DM, Kim YH, Kim JH, Baek H, Chung MJ (2008) Antitumor activity of CBT-AK5 purified from Lactobacillus casei against Sarcoma-180 infected ICR mice. J Milk Sci Biotechnol, 26, 23-30

8. Kim SJ (2005) Physicochemical characteristics of yogurt prepared with lactic acid bacteria isolated from kimchi. J Korean Soc Food Cult, 20, 337-340

9. Lee Y, Chang HC (2008) Isolation and characterization of kimchi lactic acid bacteria showing anti-Helicobacter 
pylori activity. Microbiol Biotechol Lett, 36, 106-114

10. Yoon KY, Woodams EE, Hang YD (2006) Production of probiotic cabbage juice by lactic acid bacteria. Bioresource Technol, 97, 1427-1430

11. Kim ES, Song JH, Chung HY, Jeong HS, Jang HD, Kim GN (2012) Effect of fermentation with Lactobacillus plantarum and heat processing on the anti-oxidant activity and volatile composition of garlic. Food Eng Prog, 16, 374-380

12. Yang HS, Choi YJ, Oh HH, Moon JS, Jung HK, Kim KJ, Choi BS, Lee JW, Huh CK (2014) Antioxidative activity of mushroom water extracts fermented by lactic acid bacteria. J Korean Soc Food Sci Nutr, 43, 80-85

13. Im HE, Oh YR, Kim NY, Han MJ (2013) Characteristics of cabbage juice fermented by lactic acid bacteria from kimchi. J Korean Soc Food Cult, 28, 401-408

14. Roh HJ, Kim GE (2009) Fermentation of cucurbita maxima extracts with microganisms from kimchi. KSBB, 24, $149-155$

15. Administration $\mathrm{KFaD}$ (2011) Korean food standards codex, 472-473

16. Lee KW, Kim YJ, Lee HJ, Lee CY (2003) Cocoa has more phenolic phytochemicals and a higher antioxidant capacity than teas and red wine. J Agric Food Chem, 51, 7292-7295

17. Borchers AT, Keen CL, Hannum SM, Gershwin ME (2004) Cocoa and chocolate: composition, bioavailability, and health implications. J Med Food, 3, 77-105

18. Gu L, House SE, Wu X, Ou B, Prior RL (2006) Procyanidin and catechin contents and antioxidant capacity of cocoa and chocolate products. J Agric Food Chem, 54, 4057-4061

19. Hammerstone JF, Lazarus SA, Mitchell AE, Rucker R, Schmitz HH (1999) Identification of procyanidins in cocoa (Theobroma cacao) and chocolate using high-performance liquid chromatography/mass spectrometry. J Agric Food Chem, 47, 490-496

20. Natsume M, Osakabe N, Yamagishi M, Takizawa T, Nakamura T, Miyatake H, Hatano T, Yoshida T (2000) Analyses of polyphenols in cacao liquor, cocoa, and chocolate by normal-phase and reversed-phase HPLC. Biosci Biotech Bioch, 64, 2581-2587

21. Yoon MH, Kim KH, Hwang HR, Jo JE, Kim MS, Yook HS (2009) Quality characteristics and antioxidant activity of chocolate containing flowering cherry (Prunus serrulata L. var. spontanea Max. wils.) fruit powder. J Korean Soc Food Sci Nutr, 38, 1600-1605
22. Joo NM, Kim BR, Pyo SJ (2010) Optimization of the addition of Jinuni beans to chocolate using the response surface methodology. J Korean Diet Assoc, 16, 13-21

23. Park SY, Joo NM (2011) Processing optimization and antioxidant activity of chocolate added with mulberry. Korean J Food Sci Technol, 43, 303-314

24. Foong YJ, Lee ST, Ramli N, Tan YN, Ayob MK (2013) Incorporation of potential probiotic Lactobacillus plantarum isolated from fermented cocoa beans into dark chocolate: bacterial viability and physicochemical properties analysis. J Food Qual, 36, 164-171

25. Zyzelewicz D, Nebesny E, Motyl I, Libudzisz Z (2010) Effect of milk chocolate supplementation with lyophilised Lactobacillus cells on its attributes. Czech J Food Sci, 28, 392-406

26. Homayouni RA, Mehrban RM, Aref HSR (2014) Filled chocolate supplemented with Lactobacillus paracasei. Intl Res J Appl Basic Sci, 8, 2026-2031

27. Choi KP, Chae DJ, Ryoo JE (2014) Trends of chocolate industry in Korea. Food Industry and Nutrition, 19, 14-18

28. Kwon TY, Shim SM, Lee JH (2008) Characterization of Lactobacilli with tannase activity isolated from kimchi. Food Sci Biotechnol, 17, 1322-1326

29. Guyot S, Marnet N, Laraba D, Sanoner P, Drilleau JF (1998) Reversed-phase HPLC following thiolysis for quantitative estimation and characterization of the four main classes of phenolic compounds in different tissue zones of a French cider apple variety (Malus domestica var. Kermerrien). J Agric Food Chem, 46, 1698-1705

30. Othman A, Ismail A, Ghani NA, Adenan I (2007) Antioxidant capacity and phenolic content of cocoa beans. Food Chem, 100, 1523-1530

31. Gultekin-Ozguven M, Berktas I, Ozcelik B (2016) Influence of processing conditions on procyanidin profiles and antioxidant capacity of chocolates: Optimization of dark chocolate manufacturing by response surface methodology. LWT-Food Sci Technol, 66, 252-259

32. Todorovic V, Redovnikovic IR, Todorovic Z, Jankovic G, Dodevska M, Sobajic S (2015) Polyphenols, methylxanthines, and antioxidant capacity of chocolates produced in Serbia. J Food Compos Anal, 41, 137-143

33. Cheung LM, Cheung PCK, Ooi VEC (2003) Antioxidant activity and total phenolics of edible mushroom extracts. Food Chem, 81, 249-255

34. Zhishen J, Mengcheng T, Jianming W (1999) The determination of flavonoid contents in mulberry and their scavenging effects on superoxide radicals. Food Chem, 
64, 555-559

35. Blois MS (1958) Antioxidant determinations by the use of a stable free radical. Nature, 181, 1199-1200

36. Brand-Williams W, Cuvelier ME, Berset C (1995) Use of a free radical method to evaluate antioxidant activity. LWT-Food Sci Technol, 28, 25-30

37. Re R, Pellegrini N, Proteggente A, Pannala A, Yang M, Rice-Evans C (1999) Antioxidant activity applying an improved ABTS radical cation decolorization assay. Free Radical Bio Med, 26, 1231-1237

38. Hiramoto K, Johkoh H, Sako KI, Kikugawa K (1993) DNA breaking activity of the carbon-centered radical generated from 2, 2' -azobis (2-amidinopropane) hydrochloride (AAPH). Free Radical Res Com, 19, 323-332

39. Buettner GR (1987) Spin trapping: ESR parameters of spin adducts. Free Radical Bio Med, 3, 259-303

40. He W, Liu Y, Wamer WG, Yin JJ (2014) Electron spin resonance spectroscopy for the study of nanomaterialmediated generation of reactive oxygen species. J Food Drug Anal, 22, 49-63

41. Kiselova Y, Ivanova D, Chervenkov T, Gerova D, Galunska B, Yankova T (2006) Correlation between the in vitro antioxidant activity and polyphenol content of aqueous extracts from Bulgarian herbs. Phytother Res, 20, 961-965

42. Gramza A, Khokhar S, Yoko S, Gliszczynska Swiglo A, Hes M, Korczak J (2006) Antioxidant activity of tea extracts in lipids and correlation with polyphenol content. Eur J Lipid Sci Technol, 108, 351-362

43. Larisch B, Grob U, Pischetsrieder M (1998) On the reaction of $\mathrm{L}$-ascorbic acid with propylamine under various conditions: quantification of the main products by HPLC/DAD. Eur Food Res Technol, 206, 333-337

44. Lee HS, Nagy S (1988) Relationship of sugar degradation to detrimental changes in citrus juice quality. Food Techonol-Chicago, 42, 91-94
45. Matissek R (1997) Evaluation of xanthine derivatives in chocolate - nutritional and chemical aspects. Eur Food Res Technol, 205, 175-184

46. Nehlig A, Daval JL, Debry G (1992) Caffeine and the central nervous system: mechanisms of action, biochemical, metabolic and psychostimulant effects. Brain Res Rev, 17, 139-170

47. Spiller GA (1998) Caffeine. Chpter 10. Basic metabolism and physiological effects of the methylxanthines. CRC Press LLC, Boca Raton, FL, USA, p 225-231

48. Martinez-Pinilla E, Onatibia-Astibia A, Franco R (2015) The relevance of theobromine for the beneficial effects of cocoa consumption. Front Pharmacol, 6, 1-5

49. Lee JY, Lee YJ, Park WS (2010) Anti-inflammatory effects of fermented Houttuyniae Herba water extract on LPS-induced mouse macrophage. Korean J Herbology, $25,27-34$

50. Song HS, Eom SH, Kang YM, Choi JD, Kim YM (2011) Enhancement of the antioxidant and anti- inflammatory activity of Hizikia fusiforme water extract by lactic acid bacteria fermentation. Korean J Fish Aquat Sci, 44, 111-117

51. Jung JE, Cho EJ (2011) Enhancement of Antiinflammatory Effect of Zizyphus jujuba var. inermis Fruits by Fermentation. Cancer Prev Res, 16, 263-268

52. Kang YM, Woo NS, Seo YB (2013) Effects of Lactobacillus brevis BJ20 fermentation on the antioxidant and antiinflammatory activities of sea tangle Saccharina japonica and oyster Crassostrea gigas. Korean J Fish Aquat Sci, 46, 359-364

53. Lee SY, Park SL, Nam YD, Yi SH, Lim SI (2013) Anti-diabetic effects of fermented green tea in $\mathrm{KK}-\mathrm{A}^{\mathrm{y}}$ diabetic mice. Korean J Food Sci Technol, 45, 488-494

54. Ham SH, Lim BL, Yu JH, Ka SO, Park BH (2008) Fermentation increases antidiabetic effects of Acanthopanax senticosus. J Physiol \& Pathol Korean Med, 22, 340-345 